\title{
Structural Separation to Create Competition? The Case of Freight Railways
}

\author{
RUSSELL PITTMAN * \\ Antitrust Division, US Department of Justice, and New Economic School, Moscow
}

\begin{abstract}
The freight railways sector has three attributes that have proved problematic for recent experiments with vertical separation: a) a relatively high share of network costs in total delivered service costs, b) an apparent persistence of economies of scale at the "competitive" train operations level, and, perhaps most important, c) strong economies of vertical integration that are focused on the interface point of wheel and rail - that is, exactly where vertical separation takes place. The third factor in particular seems a clear illustration of the rationales discussed by Coase and Williamson for the broad vertical scope of a single firm and the disadvantages of relying on market transactions under certain conditions.
\end{abstract}

"[UK] rail privatization was a classic example of taking a model that had worked for one industry and wrongly applying it to different circumstances." David Willetts, MP, in the Daily Telegraph (London), December 13, 2003

\section{Introduction}

The vertical separation model is an attractive model for economists and reformers seeking to restructure the old state-owned monopolies in the public utilities sectors. It promises to solve two major problems at once: by opening the upstream sector to entry, it promises to allow competition rather than regulation to determine outcomes in the upstream market, and by removing the incentive for the infrastructure operator to discriminate in favor of its affiliated upstream entity, it promises to simplify the task of regulating infrastructure access.

Unfortunately, the model has not always worked out as well in practice as it has on the blackboard. In recent years it has become apparent that the model is more likely to be successful in some sectors than in others, and in some countries at some times than in other countries at other times. ${ }^{1}$ Whether a particular sector in a particular country at a particular

\footnotetext{
* Economic Analysis Group, Antitrust Division, US Department of Justice, BICN 10-000, Washington, DC 20530. Email: russell.pittman@usdoj.gov The views expressed are not those of the US Department of Justice. The author thanks Delroy Blokland, Sean Ennis, David Tyrrall, and participants (including two anonymous referees) in the conference on Structural Separation and Access Pricing: A New Synthesis (Amsterdam, November 2003), and an anonymous referee for extremely helpful suggestions, comments, and questions.

${ }^{1}$ Newbery, 1999; von Hirschhausen, 2002; World Bank, 2002; Pittman, 2003.
} 
time is a good candidate for either vertical separation or its less extreme cousin, vertical access - that is, opening the upstream sector to non-integrated competitors while allowing the infrastructure enterprise to remain integrated - or whether other reform strategies might be more efficient and effective than either of these may depend on a number of situationspecific factors.

I would argue that one of the specific lessons of the experience to date is that the freight railways sector may not be a very promising sector for vertical separation. ${ }^{2}$ Analysts throughout the world are coming to understand ex post much better than they did ex ante that there are a number of characteristics of the freight railways sector that do not seem to fit well with the assumptions and requirements of the vertical separation model. In this case as in so many others, the devil is indeed in the details. ${ }^{3}$

\section{Share of fixed and sunk costs}

To begin with, the share of fixed and sunk costs in the total costs of providing railroad services - mainly the costs of the "grid", but other fixed and sunk costs as well - is considerably larger than the corresponding share of fixed costs in most other public utilities sectors. Thompson (2003) estimates that the infrastructure represents around 25 percent of the total delivered cost of railway services on average, while the UK's Ofwat estimates that "transport costs" make up only 5 percent of delivered costs in electricity and only 2.5 percent in gas (WRc, 2002). Gomez-Ibanez (1999) estimates that the cost share of the infrastructure in the rail sector is generally about twice that typically observed in the gas and electricity sectors. ${ }^{4}$ The rail sector may be most like the water sector in this regard, and that is a sector where vertical separation has been almost completely absent until recently. ${ }^{5}$

There are at least three important implications of this discrepancy for our purposes. First, if the "natural monopoly" portion of a sector is larger, the potentially competitive portion is necessarily smaller. If the forces of competition have perhaps ninety to ninetyfive percent of the total delivered costs of electricity in which to improve efficiency, they have only perhaps seventy-five percent of the total delivered costs of railway services - not a trivial difference. The same policy reforms would, ceteris paribus, have only 7.5/9 as much efficiency benefit in the railway sector as in the electricity sector, and that suggests a higher policy priority for vertical restructuring in the latter.

Second, along with the importance of fixed costs and the relatively high value of the grid network comes the importance of instituting the appropriate incentives for

\footnotetext{
${ }^{2}$ In this paper we focus on the freight railway sector only; we do not consider the passenger railway sector in detail. Passenger railways raise a number of different issues from freight, and the analysis tends to be dominated by a) the positive externalities resulting from keeping passenger cars off the road, and b) not unrelated, the fact that passenger railways, both commuter and long-distance, are heavily subsidized by governments (or, though decreasingly, by freight operations) in almost every case. The principal exceptions, the cases where passenger operations pay their own way, are Japan and Singapore, and in Japan this is accomplished in part through heavy road tolls.

${ }^{3}$ This author claims no superior ex ante insight; see Ordover and Pittman (1993).

${ }^{4}$ See also BTRE (2003) at 6 and 20, Newbery (1999) at 201 and 343, and Welsby and Nichols (1999).

${ }^{5}$ According to Gee (2004), "the fixed costs linked to water distribution and waste water collection represent up to 70 percent of the total supply costs for domestic customers, and this is largely a sunk cost." See also Noll et al (2000), Bailey (2002), EBRD (2004), and Meister (2005).
} 
maintenance, improvements, and other investments. But the question of getting the incentives right for investment seems at this point to be a serious weakness - perhaps the most serious weakness - of the vertical separation model, in railways but not only in railways.

In practice it has been difficult to set access prices in such a way that non-integrated rail infrastructure companies have the correct incentives for maintenance and improvements. This problem has been exacerbated by attempts to increase short-run trainpath allocation efficiency by using peak-load access pricing; infrastructure operators that receive higher access fees for capacity that is scarce in particular situations may not have good incentives to eliminate that scarcity. (To my knowledge, there has been little experimentation in the rail sector with "decoupling" the peak-load access fees paid by train companies from the fees received by their infrastructure providers.) Problems with poor incentives for system maintenance and improvement have been identified as perhaps the single greatest weakness of the UK experiment with vertical separation in railways. ${ }^{6}$

Third, and related to this point, the higher the level of fixed costs, the more difficult are the trade-offs involved in setting prices that both encourage efficiency of usage and allow for the grid operator to recover its fixed costs. ${ }^{7}$ This point is well understood in principle and among railroad policy makers and reformers in Western Europe, but it may not be so well understood in the accession and other developing countries. When fixed costs are important - and again, the point here is that they seem to be more important in the railways sector than in most other infrastructure sectors - then marginal costs are below average costs up to the range of diminishing returns. In this situation, access pricing that is efficient in the short run does not cover the costs of the network, while access pricing that covers the cost of the network may inefficiently deny access to lower-margin users.

The usual and traditional way of pricing the services of a regulated monopoly to allow for the recovery of costs, including a return on capital, is "fully allocated cost", or "average cost", pricing. The addition, or "allocation", of a share of fixed costs to marginal costs allows full cost recovery by the providing firm but results in a price that will exclude from service those potential users whose valuation of the service is higher than marginal cost but less than marginal cost plus allocated cost, and this exclusion is allocatively inefficient.

There are only two broad alternatives to the inefficiencies of fully allocated cost pricing: government subsidies to infrastructure and discriminatory access charges. The former, government subsidies, are the policy contemplated for the rail sectors of many Western European countries, but they suffer from the usual bad incentive properties of creating enterprises with soft budget constraints, as well as the disadvantages inherent in the involvement of government in the day-to-day decision-making of the enterprise and the inefficiencies involved in raising government funds by taxation. On that point, it is important to note also that the shadow price of government funds is much higher in developing countries, with their poorly operating systems of public finance, than in an average OECD or EU country - sometimes more than one dollar extra per dollar spent in the former countries. ${ }^{8}$

On the other hand, discriminatory access charges, whether of the Ramsey (third degree) or two-part tariff (second degree) variety of discrimination, though they have good efficiency properties, have already run directly into objections and challenges from EU and

\footnotetext{
${ }^{6}$ BTRE (2003); Gomez-Ibanez (2003); Mercer Management Consulting (2003).

${ }^{7}$ This issue is discussed more extensively in Pittman (2004a). See also Nash and Matthews (2002).

${ }^{8}$ See, for example, Jones, Tandon, and Vogelsang (1990) and Newbery (1999), chapter 3.
} 
EU country competition law enforcers. The clearest, but hardly the only, example is Germany, where the railway enterprise Deutsche Bahn AG set its access charge in the form of a two-part tariff: a flat annual charge independent of usage and a variable charge dependent on the level of usage. In order not to discourage small, independent train operators that might not be able to pay the flat portion of the charge, DB also offered an access charge regime with no flat fee but with a higher variable charge. The German competition authority, the Budeskartellamt, objected that with this "menu" of charges and even with the original two-part tariff itself - more intensive users of the infrastructure would pay a lower fee ex post per level of usage overall, as the flat fee paid was spread over larger volumes of traffic. (The fact that the integrated incumbent DB would, at least at the outset, pay the lowest overall fee of any train operating company was certainly not lost on the Bundeskartellamt.) DB avoided enforcement action under the abuse-of-dominance provisions of the German competition law only by replacing the two-part tariff with a single per-unit tariff that is identical for all train operating companies. ${ }^{9}$

It has not availed DB and other infrastructure enterprises to argue that the "discrimination" that is of concern in competition laws and "equal access" discussions may be different in principle from the "discrimination" used by an enterprise with a diverse set of customers to cover its fixed costs - especially when, as in the DB case, the outcomes of the two kinds of discrimination may be indistinguishable in practice. So long as both these types of discrimination are considered equally suspect by reformers and regulators, there is no obvious escape from this broader policy conundrum.

\section{Upstream economies of scale}

The second way that freight railroads are different from many other infrastructure industries is in the apparent importance of economies of scale in the "upstream" sector that is, train service for railroads - relative to those observed in generation for electricity, gas production for gas, "value added services" such as long-distance, mobile and internet service for telecommunications, and so on. It appears now that in the electricity industry, so long as there is a cheap and reliable supply of gas, small gas generating enterprises can be competitive with larger enterprises using other generation technologies - though, as the California experience has shown, there may remain serious difficulties in the attempt to create workably competitive generation markets. Similarly, it does not appear that a gas production facility must be of large size relative to its pipeline or customers to be of efficient scale. ${ }^{10}$ To a similar but lesser degree, the experience to date suggests that valueadded telecommunications service markets are very often oligopolistic in structure, supporting at least a small group of competing enterprises.

The experience, and the econometric estimates, in the railway industry are not as friendly to upstream competition. The best econometric work has consistently suggested that over a broad range of track network sizes, there are significant economies of density to the operation of freight trains - that is, the costs of a train operating enterprise on a given

\footnotetext{
9 "Reform of DB AG's route price system to comply with competition," Bundeskartellamt, September 8, 2000; "Proceedings against Deutsche Bahn AG in connection with abusive route price structure halted," Bundeskartellamt, March 20, 2001.

${ }^{10}$ See, generally, Newbery (1999).
} 
track network decline with ton-km of output. ${ }^{11}$ In other words, a freight trains market opened up to competition may in most circumstances naturally tend toward dominant firm oligopoly or even monopoly.

This has been the experience, again broadly speaking, in countries as diverse as Sweden, the Czech Republic, Romania, and Australia (BTRE, 2003; and Owen, 2003) though it should be noted as well that a) the policy of vertical separation is a fairly recent one in most of these countries, and b) the trend of market share of the smaller freight operators in these countries is almost universally positive. ${ }^{12}$ The situation of dominance by the incumbent is similar in Russia, though it is true that the railway reforms are even more recent there than in many other countries (and in Russia there is at this point only vertical access, not vertical separation). In Russia, the liberalizing of access to the rail infrastructure has so far resulted in only three independent train companies operating their own trains with their own locomotives on the track of the integrated company RZhD, with all of them carrying just a single commodity, oil (OECD, 2004). ${ }^{13}$

Vertically separated railway sectors have thus far tended toward bilateral monopoly not what the designers of the policy had in mind, and suggesting that the significant costs involved in vertical separation in this sector may bring only limited benefits.

\section{The locus of vertical separation}

Third, railroads are different from many other infrastructure industries in the degree to which the effectiveness of the operations depends on the exact point where vertical integration or vertical separation takes place. Rothengatter (2002) argues that in the railways sector "the technological interdependence between vehicle technology and infrastructure technology is a crucial point in decision making." 14

Certainly the point of access and the quality of access are crucial determinants of the quality of other infrastructure services, such as electricity and telecommunications, as well. But there seems to be a difference in kind between these sectors and the railroad sector, where so much of the investment, so much of the efficiency, and so much of the safety depend on the exact point of intersection between the steel wheels of the rolling stock and the steel rails of the grid. In contrast, Newbery (1999) argues that in the telecommunications sector it is not even possible to state with certainty where an optimal point of vertical separation might be.

\footnotetext{
${ }^{11}$ The best recent study is that of Ivaldi and McCullough (2001). See also Wilson (1997), Freebairn (1998), and Savignat and Nash (1999).

${ }^{12}$ The slightly ambiguous evaluation presented here is echoed in the report of a recent round table of the European Conference of Ministers of Transport (2003). The "conclusions" of the round table include oddly paired statements that "The possibility of free access to the EU network has been little used up to now" and "The facts seem to prove that new companies can overcome barriers to entry without too much difficulty", as well as a statement that "privatization [has] worked well for freight" in the UK, tempered later by reference to "the differences of view [within the round table] on the United Kingdom's experience with rail privatization."

${ }^{13}$ As noted in Cheviakhova (2004), public statements by the RZhD president and others suggesting that there has been much more entry than this by a large number of "operating companies" or "carriers" "are literally accurate but may be misleading: the companies referred to may own rolling stock and act as freight forwarders or train assemblers, but they rely on RZhD for locomotives and train operation."

${ }^{14}$ See also Ksoll (2004).
} 
This point is of course related to the first point - the importance of the grid in overall sector costs - but it is separable from it. An examination of the railways trade press reveals that a large portion of the discussion of possible technological improvements in the railways sector is focused on the ways that differences in rolling stock design and wheel design affect track wear, track maintenance requirements, and optimal track design, as well as the converse - the ways that track design and maintenance may affect rolling stock. Some examples are instructive:

\begin{abstract}
"The modern railway environment of increasing axle loads, faster and longer trains, higher-adhesion locomotives, and greater cant deficiencies are all increasing the demands on the wheel/rail interface." ("Stress Reduction, Railroad Style," Railway Age, July 2002)
\end{abstract}

\begin{abstract}
"The point where steel wheel meets steel rail is about the size of a dime, but bad profiles on one or both can lead to millions of dollars worth of problems for railroad car and maintenance-of-way people." ("Where Steel Meets Steel," Railway Age, May 2002)
\end{abstract}

\begin{abstract}
"Vertically-integrated railways offer an excellent opportunity to optimize the 'total system' by ensuring that each element and each component is combined in sub-systems that work together and optimize the whole. An example is the optimization of the wheel-rail contact by establishing mutually compatible profiles that minimize contact stresses and wear while balancing curving and running stability performance. Optimizing contact surface friction through lubrication and restoration of rail profiles, and wheel profile maintenance enter the equations. At the next level, [freight and passenger car] suspension systems are tuned and modified to complement both curving and stability performance while accommodating track geometry and ride quality demands." ("North American Railfreight Benefits from Technical Advances," International Railway Journal, August 2002)
\end{abstract}

The technical engineering literature makes the same point. Zarembski and Blaze (2003) examine the economic implications of the trend toward heavier axle loads in freight railways and note that not only do heavier loads increase track wear and thus maintenance and replacement costs, but that the degree of these increases very much depends upon both location (terrain, grade, bridges) and the nature of other track usage. Similarly, Zarembski (1997) considers a now common track maintenance procedure called "grinding" and notes how difficult it is to separate the benefits in the prevention of infrastructure wear and fatigue from grinding from the benefits of many other factors, including wheel lubrication and maintenance. Moreover, the effects of grinding and above-track expenditures go both ways: proper grinding results in reduced wheel wear and fuel consumption for train operations. $^{15}$

Finally, an examination of the investigations of the causes of railways accidents reveals an emphasis on the same technological locus, the point where steel wheels meet steel track. The most well known example is the fatal Hatfield accident in the UK. Gomez-Ibanez (2003) notes in his discussion of this event that "some observers suspected that the track was being damaged by train wheels with flat spots in them, and that flat wheels had increased because of poor train maintenance by the ROSCOs [rolling stock leasing companies]." ${ }^{\prime 16}$ Even before the Hatfield accident, though, a report commissioned by the UK's Office of the Rail Regulator noted the incentive problems with vertical separation:

\footnotetext{
${ }^{15}$ See also Samuels et al (2003) and Smulders et al (2003).

${ }^{16}$ See also Mercer Management Consulting (2002) and Clark et al (2003).
} 
While wheel irregularities are known to lead to track damage ... there is less evidence that they adversely affect the vehicle structure.... Thus in a railway system where vehicle owners and maintainers are insulated from direct track damage costs (such as the situation that now exists in Britain), there is less pressure on the mechanical side to maintain wheels in good condition. (TCCI, 2000, at A-30, cited in BTRE, 2003, at 140)

In general, as BTRE (2003) notes, there is some irony in the fact that "access reform policy is occurring at a time when technological developments are increasingly focused on the wheel-rail interface ..."

It is true that even in countries where the freight railways have remained vertically integrated, like the US and Canada, there are many shippers who own their own rolling stock, and there are rolling stock leasing companies and pools (such as TTX, a flatcar pool that is a joint venture of the Class I railroad companies in the US) that separate the ownership of the rolling stock itself from the ownership of the infrastructure. Nevertheless this "independent" rolling stock is under the complete control of the integrated railway enterprise during the time that it is providing service, and the integrated railway enterprise has good incentives to maintain the rolling stock appropriately and to refuse to utilize rolling stock that is of poor quality.

The point is that a great deal of the short-term and long-term efficiency of the provision of rail services depends on the successful coordination of this point of intersection between steel wheels and steel rails. Coase (1937) and Williamson (1975) - among others explained decades ago how and why coordination like this might take place more successfully within a firm than between independent firms. Ten years ago, Chris Nash wondered aloud at an OECD conference in Budapest whether the rail industry in the UK or elsewhere was ready to be recreated as a giant laboratory for Williamson's Markets and Hierarchies (OECD, 1994). The recent econometric results of Ivaldi and McCullough (2004), examining subadditivity in the railway sector, suggest that "there would be a 20-40 percent loss of technical efficiency if railroad freight operations were separated from infrastructure." And yet it is remarkable how little of the discussion of vertical separation in this sector has focused on the loss of inter-enterprise economies of scope across vertical levels of operation. ${ }^{17}$

\section{Competition: The primary goal of restructuring}

This raises an obvious question. If there are significant costs and difficulties involved in vertical separation and vertical access in the rail sector, why would anyone advocate the implementation of such policies? Perhaps the answer seems obvious, but it may be useful to keep the overall goals and objectives firmly in focus, so that we may continue to consider whether vertical separation or vertical access is the best way to achieve them.

In fact there may be several policy mandates behind railways restructuring in a particular situation - the reduction or elimination of an ongoing drain on the state budget (as in many or most countries that have had monopoly, state-owned railways), the equalization of the terms under which different modes of transport compete with each

\footnotetext{
${ }^{17}$ Fraquelli et al (2004) and Michaels (2004) provide comparable findings and discussions in the electricity sector.
} 
other (especially in Sweden), the improvement of economic efficiency through the transfer of decision making from the public to the private sector (especially in the UK), the furthering of geographic integration among independent or federated states (the European Union, Australia) - but typically the most important is the creation of competition - of economic choices - for shippers of goods, coupled with the hope that competition can replace regulation as the day-to-day governor of industry outcomes. These shipper choices, then, in the classic antitrust policy context, are to protect customers from suffering the high prices and poor service typically observed in monopoly situations. If this is the most important rationale for vertical restructuring, let us ask the question, what other possible means are on the menu of policy options for achieving them - for protecting the customers?

\subsection{Policy options for the creation of competition}

The first and most obvious option to be relied upon is intermodal competition competition for the business of the shipper from motor carriers or water carriers. Railroads may be in many cases natural monopolies without monopoly power, because many shippers can switch to these other modes if they are dissatisfied with their rail service, and because both the motor carrier and the water carrier sector tend to have low barriers to entry and so to be structured fairly competitively - thus providing a relatively flat cost curve ceiling above which rail rates cannot go. ${ }^{18}$ The presence of intermodal competition has been the dominant force behind the deregulation of rail freight tariffs in Western Europe and the US over the past twenty years (Winston et al, 1990).

Unfortunately, however, not all shippers can rely on intermodal competition for protection from monopoly abuses by rail carriers. Many rail shippers are not served by water. Some rail shippers, especially in extreme climates like northern Siberia, are not served by roads, at least not for all twelve months of the year. More fundamentally, though, some commodities cannot be shipped, or cannot be shipped economically, by motor carrier. It is a characteristic of "bulk" commodities - commodities that are low in value relative to their weight and volume - that they in many cases can be shipped economically only by rail - again, where the water option is not present - and this is especially the case as the distances shipped get longer. In many countries now, including most of Western Europe, the speed and convenience of motor carriers have caused most of the high-value goods to be shipped on the highways, and the lion's share of rail freight is long-distance shipments of low-value commodities like coal, other mineral ores, timber, and grains. Shippers of these commodities - and again, especially over long distances usually cannot rely on motor carriers to provide competition to rail. ${ }^{19}$

Those shippers who are thus "captive" to the rail mode must, by definition, have a choice of alternate rail carriers if they are to enjoy competitive transport options. Two very different classes of rail restructuring models have been chosen by policy makers for providing these options. ${ }^{20}$ One, characteristic of many North and South American countries - and especially the larger ones - has been to create a system whereby shippers are served by more than one vertically integrated railway company - that is, by multiple companies each consisting of a stock of infrastructure (track, signals, stations, and so on) and trains,

\footnotetext{
${ }^{18}$ This is not as true for the less-than-truckload (LTL) segment of the motor carrier sector as it is of the truckload (TL) segment. However, it is the TL segment that most closely with competes with rail.

${ }^{19}$ See, e.g., Pittman (1990) and Kwoka and White (2004).

20 These two models are discussed in greater detail in Pittman (2004b).
} 
and each part of a single corporate structure. The other class, characteristic of many Western European - and, increasingly, Central and Eastern European (Cheviakhova et al, 2004) - countries and the object of a series of EU Directives, creates a system whereby a single, unified infrastructure grid has multiple train companies operating on it, competing to serve individual shippers using a single infrastructure. Let us call these two classes the "American" and "European" models for convenience. Each of these two classes of models has displayed in turn two sub-models.

\subsection{The Americas: Maintaining vertical integration}

In the US and Canadian versions of the American model, most - though far from all - of the competition provided to individual shippers is so-called "parallel" competition - that is, two or more vertically integrated train and track companies serve both the origin and the destination of the traffic, and they compete for the business of those who want to ship their commodities between that origin and that destination by trying to offer better pricing, more reliable service, and so on. This is probably the ideal system from the viewpoint of the shipper, at least in the short term, but it may suffer from two disadvantages as a policy suboption. First, competing vertically integrated railway enterprises between the same two points may not take advantage of the available economies of density to train operation. Second, and related, in those countries unlucky enough not to have a heritage of private railway companies building their own competing parallel infrastructures, constructing competing parallel tracks may be considered prohibitively expensive today.

In the second version of the American model - what we may call the Latin American sub-model - most of the competition among vertically integrated train companies is not between the same origin and the same destination, but rather among competing companies offering to carry the cargo from a single origin to customers at different destinations, and, separately, competing to carry cargos from different origins to a customer at a single destination.

This form of competition, often called "geographic competition" or "source competition", is also a feature of the US and Canadian railways, but there it complements parallel competition. In Mexico and Argentina, and to a lesser extent Brazil - to take the three most important Latin American examples - there is not much parallel rail competition, but the systems were restructured and privatized in the 1990's in such a way that shippers at the most important rail shipping locations usually have the choice of two, and sometimes more, independent, vertically integrated railway enterprises competing to ship their cargo. ${ }^{21}$ In Mexico, for example, firms seeking to ship goods by rail from Mexico City and firms seeking to have goods delivered by rail to Mexico City are served by the Northeastern (TFM), North Pacific (Ferromex) and Southeastern (Ferrosur) railways, and these three vertically integrated railway companies can compete among each other to provide service.

Broadly speaking, these reforms have been considered quite successful; the introduction of the Latin American sub-model has occurred concomitantly with a renaissance of the rail sector in these three countries. On the other hand, not every shipper is indifferent as to which direction his freight is hauled, and that is the obvious disadvantage of the Latin American sub-model.

\footnotetext{
${ }^{21}$ For Argentina, see Kohon (1995) and Kogan (2002); for Brazil, see Estache et al (2001); for Mexico, see Garcia de Alba (2000).
} 


\subsection{Europe: Vertical access and vertical separation}

The European model of competing train companies operating on a monopoly infrastructure similarly has two sub-models in practice: some countries have maintained a degree of vertical integration in the train sector by allowing the enterprise that controls the infrastructure to operate trains as well, in competition with non-integrated train operating companies, while other countries have imposed complete vertical separation between the infrastructure and operating sectors. We may call these two sub-models the vertical access and vertical separation models, respectively.

The idea behind the vertical access model is to create competition among train operators while maintaining the economies of vertical integration between the infrastructure operator and the existing train operator. Unfortunately it is difficult to name a country where this model has been obviously successful. Most common has been the case that non-integrated train companies have been allowed to enter the markets but have been unable to gain much market share against the entrenched incumbents (though, as noted earlier, in general their shares are slowly increasing). A small number of large European carriers - IKEA and Rail4Chem are two examples, but there are others - have been created by commodity shippers backwards integrating into train operations, and these large shippers, along with others like them who may have threatened to backward integrate, may have profited from the vertical access policy. But for the average shipper of bulk commodities, not much competition has been created - at least not yet. ${ }^{22}$

There are a number of reasons for what we may call this (again, thus far) disappointment. The first may be something of a logical fallacy: if the integrated train company enjoys vertical economies - which indeed is apparently the reason for allowing it to remain integrated - then it follows that most non-integrated train operators, not enjoying such economies, will be at a disadvantage to the integrated company in competing for business. This is especially the case since the success of the vertical access model would also seem to depend on the ability of the sectoral regulator or competition authority to prevent the vertically integrated company from offering discriminatory access terms that favor its own train operator over non-integrated train operators, and in practice this has been a difficult task, an especially difficult one in developing and transition economies without experienced regulators (World Bank, 2002). It is also, of course, a difficulty not exclusive to the railways sector.

And there may be a bit of a further fallacy here as well: as we noted above, to the extent that the regulator forces the infrastructure operator to offer access to integrated and non-integrated train users alike at non-discriminatory terms, it may reduce the ability of the infrastructure operator to cover its fixed costs through access fees. Identical, nondiscriminatory access fees that are set at marginal cost do not cover fixed costs, while identical, non-discriminatory access fees that cover fixed costs impose what may be a large welfare cost on the economy by denying infrastructure access to those enterprises whose value of use would be below average cost but above marginal cost (Nash and Matthews, 2002; BTRE, 2003; Peter, 2003; and Pittman, 2004a). The vertical access model remains a work in progress, not an obvious failure but not yet a success, either.

\footnotetext{
${ }^{22}$ Groot (2003) provides a small number of additional examples of competition created in the European Union. Cheviakhova et al (2004) provide examples of small-scale entry by nonintegrated freight train operating companies in Central and Eastern Europe.
} 
This is not to say, however, that the vertical separation model has fared all that much better in the railways sector. The rationale behind a sub-model of vertical separation rather than what we are calling vertical access is of course to eliminate the difficult regulatory task of preventing discrimination in access terms by eliminating the incentive for the infrastructure operator to discriminate.

This was the idea behind railways restructuring in the UK (along with, as noted above, the desire to substitute decision-making by private companies for that by governmentowned companies). However, the UK experience - though not without its successes, in terms of increased freight and passenger business and competition among input suppliers, for example - is generally counted as a defeat rather than a victory for the vertical separation model (BTRE, 2003; and Gomez-Ibanez, 2003). Railtrack, the infrastructure operator, eventually was placed in administration (bankruptcy) as a result of dramatic cost increases imposed following the Hatfield accident, increases which track access fees (even with the government's subsidies to passenger train operations) were wholly inadequate to cover. The UK government and the industry continue to search for the best way to further restructure the restructured.

Note again, however, that we are discussing here freight railways only, not passenger railways. As Biggar (2004) and others have pointed out, the vertical separation and vertical access models may be much more promising policy options for those railways that are primarily passenger rather than freight carriers - in particular, the railways of the UK and other countries in western Europe. The structures of both costs and demand in markets for passenger rail service render competition in the market increasingly uneconomic and competition for the market a correspondingly more attractive option. Franchise bidding under the latter paradigm requires something like vertical access by definition, and many (though by no means all) problems may be avoided by substituting full vertical separation for vertical access in this regard. This is one more example of the importance of the particular setting involved when one considers the benefits and costs of vertical separation.

\section{The railway sector is different}

What is the problem with vertical separation in the freight railroad sector? The problem is that freight railroads are different from infrastructure sectors where there is more, and more successful, experience with vertical separation, in particular electricity, natural gas, and telecommunications (Newbery, 1999). They are different from these other infrastructure sectors in ways that are likely systematically to make vertical separation a difficult policy to implement. The relatively higher level of sunk and fixed costs in railroads means that difficulties in creating the right incentives for investment impose a heavier cost in railways than elsewhere, and mean that the trade-off in access pricing between short-term efficiency and long-term efficiency (that is, both full cost recovery and procompetitive investment) is more stark in railways than elsewhere. The apparently nonvanishing economies of density in train operation mean that even if a given infrastructure grid is opened to entry by competing train operators, that operator that achieves a "first mover" advantage is likely to keep it, and to be able to set and adjust its tariffs in such a way as to prevent the development of significant competition. The degree to which the day-to-day business of operating the rail sector is focused on the precise point where vertical separation takes place means that the loss of Coasian and Williamsonian 
efficiencies in breaking up going concerns is likely to be greater in the rail sector than elsewhere.

What this analysis suggests, then, is similar to the conclusion that David Newbery offers in his Privatization, Restructuring, and Regulation of Network Utilities (1999) and that the World Bank offers in the last-but-one World Development Report (2002), Building Institutions for Markets: that liberalizing and restructuring the infrastructure sectors of a modern economy may require very different steps leading to very different outcomes in different settings. What works in one country at one time may not work in another country at another time. And what works in electricity or gas or telecommunications may not work in rail.

\section{$7 \quad$ References}

Bailey, D. (2002) "The Emerging Co-existence of Regulation and Competition in the UK Water Industry," World Competition, 25: 127-158.

Biggar, D. (2004) On the Structural Reform of Railways. OECD: Paris.

Bureau of Transport and Regional Economics (2003) "Rail Infrastructure Pricing: Principles and Practice," Report 109, Canberra, Australia.

Coase, R, (1937) “The Nature of the Firm,” Economica, 4: 386-405.

Cheviakhova, E., G. Friebel, S. Guiev, R. Pittman, and A. Tomová (2004) "Railroad Restructuring in Russia and Central and Eastern Europe: One Solution for All Problems?" Think Tank Partnership Program, IRIS Center, University of Maryland. http://papers.ssrn.com/sol3/papers.cfm?abstract $\mathrm{id}=623963$

Clark, S., M. Dembosky, and A. Doherty (2003) "Dynamic Wheel/Rail Interactions Affecting Rolling Contact Fatigue on the British Railway System," World Congress on Railway Research, Conference Proceedings, Edinburgh, September.

Estache, A., A. Goldstein, and R. Pittman (2001) "Privatization and Regulatory Reform in Brazil: The Case of Freight Railways," Journal of Industry, Competition and Trade, 1: 203-235.

European Bank for Reconstruction and Development (2004) Transition Report 2004. European Bank for Reconstruction and Development: London.

European Conference of Ministers of Transport (2004) European Integration of Rail Freight Transport (Round Table 125). ECMT: Paris.

Fraquelli, G., M. Piacenza, and D. Vannoni (2004) "Cost Savings from Generation and Distribution with an Application to Italian Electric Utilities," Unpublished Paper, HERMES, Center for Research on Regulated Services, Moncalieri, Italy. 
Freebairn, J. (1988) “Access Prices for Rail Infrastructure," Economic Record, 74: 286296.

Garcia de Alba, P. (2000) "Competition Issues in the Privatization of the Mexican Railroads," Paper Presented at the OECD Seminar on Railway Reform, Restructuring, and Competition, Moscow, December.

Gee, A. (2004) "Competition and the Water Sector," Competition Policy Newsletter, Competition Directorate-General of the European Commission, Summer.

Gomez-Ibanez, J. (1999) "Regulating Coordination: The Promise and Problems of Vertically Unbundling Private Infrastructure," Discussion Paper, Taubman Center for State and Local Government, Harvard University.

Gomez-Ibanez, J. (2003) Regulating Infrastructure: Monopoly, Contracts, and Discretion. Harvard University Press: Cambridge, MA.

Groot, H. (2003) "Integration of Accession Countries in the EU: The Case for Railways," Rail International, 2, 2-13.

Ivaldi, M., and G.J. McCullough (2001) "Density and Integration Effects on Class I U.S. Freight Railroads," Journal of Regulatory Economics, 19: 161-182.

Ivaldi, M., and G.J. McCullough (2004) "Subadditivity Tests for Network Separation with an Application to U.S. Railroads," CICT Toulouse. http://papers.ssrn.com/sol3/results.cfm

Jones, L., P. Tandon, and I. Vogelsang (1990) Selling Public Enterprises: A Cost-Benefit Methodology. MIT Press: Cambridge, MA.

Kogan, J.H. (2002) "Argentina's Approach to Placing the Railway in Private Hands," Paper Presented at the OECD and Development Research Center of the State Council of the People's Republic of China Seminar on Railway Reform, Restructuring and Competition, Beijing, January.

Kohon, J.C. (1995) "Argentina Railways Case Study," in Ron Kopicki and Louis Thompson (ed.), Best Methods of Railway Restructuring and Privatization. World Bank: Washington.

Ksoll, M. (2004) "Integration of Infrastructure and Transport: An Assessment from Industrial Economics and Railway Perspectives," Paper Presented at the $2^{\text {nd }}$ Conference on Railroad Industry Structure, Competition and Investment, Evanston, IL, USA, October.

Kwoka, J.E., Jr., and L.J. White (2004) "Manifest Destiny? The Union Pacific and Southern Pacific Railroad Merger," in John Kwoka and Lawrence White (ed.), The Antitrust Revolution: Economics, Competition, and Policy, (4 ${ }^{\text {th }}$ edition). Oxford University Press: New York. 
Meister, U. (2005) "Do Welfare Maximizing Water Utilities Maximize Welfare under Common Carriage?" Unpublished Paper, University of Zurich, Institute for Strategy and Business Economics. http://econwpa.wustl.edu/eps/othr/papers/0505/0505001.pdf

Mercer Management Consulting (2002) The GB Rail Industry: In Its Own Words. Mercer Management Consulting: London.

Michaels, R.J. (2004) "Vertical Integration and the Restructuring of the U.S. Electricity Industry," Unpublished Paper, California State University, Fullerton, September.

Nash, C., and B. Matthews (2002) "Implementing Rail Infrastructure Charging Reform: Barriers and Possible Means of Overcoming Them," Paper Presented at the $2^{\text {nd }}$ seminar of the IMPRINT-EUROPE Thematic Network, "Implementing Reform on Transport Pricing: Identifying Mode-Specific Issues,” Brussels, May.

Newbery, D.M. (1999) Privatization, Restructuring, and Regulation of Network Utilities. MIT Press: Cambridge, MA.

Noll, R., M.M. Shirley, and S. Cowan (2000) "Reforming Urban Water Systems in Developing Countries," in Anne O. Krueger (ed.), Economic Policy Reform: The Second Stage. University of Chicago Press: Chicago.

OECD (1994) Proceedings of the OECD/World Bank Conference on Competition and Regulation in Network Infrastructure Industries. Budapest, June/July.

Ordover, J.A., and R.W. Pittman (1994) "Restructuring the Polish Railway for Competition," Economic Analysis Group Discussion Paper EAG 93-10, September 13, 1993, Revised version in OECD (1994), U.S. Department of Justice, Antitrust Division.

Owens, H. (2003) "Rail Reform Strategies: The Australian Experience," NBER Working Paper W9592, March.

Peter, B. (2003) "Rail Infrastructure Charging in the European Union," Paper Presented at the Workshop on Applied Infrastructure Research, TU Berlin, October.

Pittman, R.W. (1990) "Railroads and Competition: The Santa Fe/Southern Pacific Merger Proposal," Journal of Industrial Economics, 34: 25-46.

Pittman, R.W. (2003) "Vertical Restructuring (or Not) of the Infrastructure Sectors of Transition Economies," Journal of Industry Competition \& Trade, 3: 5-26.

Pittman, R.W. (2004a) "Russian Railways Reform and the Problem of Non-Discriminatory Access to Infrastructure," Annals of Public and Cooperative Economics, 75: 167-192.

Pittman, R.W. (2004b) "Chinese Railway Reform and Competition: Lessons from the Experience in Other Countries," Journal of Transport Economics and Policy, 38: 309-332. 
Rothengatter, W. (2002) "How Good Is First Best? Marginal Cost and Other Pricing Principles for User Charging in Transport," Working Paper, University of Karlsruhe, October.

Samuels, J., S. Kalay, and D. Iler (2003) "Reducing the Stress State of the North American Railroads," Proceedings of the International Heavy Haul Association 2003 Specialist Technical Session, Dallas, May.

Savignat, M.G., and C. Nash (1999) "The Case for Rail Reform in Europe - Evidence from Studies of Production Characteristics of the Rail Industry," International Journal of Transport Economics, 26: 201-217.

Smulders, J., M. Heinsch, and T. Bontekoe (2003) "RCF Management and Research Program in the Netherlands: Approach and Solutions to Control the Wheel/Rail Interface to Reduce RCF Damage," World Congress on Railway Research, Conference Proceedings, Edinburgh, September.

TCCI (2000) Rail Failure Assessment for the Office of the Rail Regulator: An assessment of Railtrack's Methods Managing Broken and Defective Rails. http://www.railreg.gov.uk/docs/tccireport.pdf

Thompson, L. (2003) "The Regulatory Challenge in Russian Railways," Presentation at OECD Seminar on Railways Reform, Moscow, May.

Von Hirschhausen, C. (2002) Modernizing Infrastructure in Transformation Economies: Paving the Way to European Enlargement. Edward Elgar: Cheltenham, UK.

Welsby, J., and A. Nichols (1999) "The Privatisation of Britain's Railways: An Inside View," Journal of Transport Economics and Policy, 33: 55-76.

Williamson, O.E. (1975) Markets and Hierarchies: Analysis and Antitrust Implications. Free Press: New York.

Wilson, W.W. (1997) "Cost Savings and Productivity in the Railroad Industry," Journal of Regulatory Economics, 11: 21-40.

Winston, C., T.M. Corsi, C.M. Grimm, and C.A. Evans (1990) The Effects of Surface Freight Deregulation. Brookings: Washington.

World Bank (2002) World Development Report 2002: Building Institutions for Markets, World Bank: Washington.

WRc plc (2002) Study on the Application of the Competition Rules to the Water Sector in the European Community. Prepared for the Competition Directorate-General, European Community, Wiltshire, UK.

Zarembski, A.M. (1997) "On the Benefits of Rail Maintenance Grinding," American Railway Engineering Association Annual Technical Conference, Bulletin 760, Volume 98, Chicago, March. 
Zarembski, A.M., and J. Blaze (2003) "The Economics of Heavy Axle Loads: Costs and Benefits," International Railway Journal, April. 